\title{
A Retrospective Study of the Management of HIV, Hepatitis B and Hepatitis C-Positive Pregnancies in Edinburgh, UK from 1997-2002.
}

\author{
Wendy J. Russell *.
}

STUDY AIMS: This study aims to examine management practices for HIV-positive, HBV-positive and HCV-positive pregnancies over 1997-2002 in Edinburgh, UK, and the effects the diseases have on pregnancy outcomes. RESULTS: Equally for $\mathrm{HIV}, \mathrm{HBV}$, and $\mathrm{HCV}, 50 \%$ of the diagnoses were made before pregnancy while the other $50 \%$ were detected and diagnosed through antenatal testing. Of the $17 \mathrm{HBV}$-positive pregnancies $31.6 \%$ of the women were highly infectious at delivery and $57.9 \%$ were carriers with low infectivity. Of the $17 \mathrm{HIV}$-positive pregnancies $47.1 \%$ of the women had an undetectable viral load and $\mathbf{1 7 . 6 \%}$ were unrecorded at delivery. All 17 HIV-positive pregnancies received ART in varying regimes, $15(88.2 \%)$ were on combination therapy, one delivered vaginally and no women breastfed. All neonates of $\mathrm{HBV}$-positive mothers received immunoglobulin and vaccination and were then breastfed. There were no specific interventions for HCV. Only one study child out of the 38 pregnancies became infected, and this was with HIV. CONCLUSION: Routine screening identifies women with no obvious risk factors, and interventions are largely accepted and effective at reducing vertical transmission. HIV therapy is individually tailored and increasingly uses several agents. Moreover, there is a movement towards allowing low viral load HIV-positive women to deliver vaginally. There are no interventions recommended for $\mathrm{HCV}$ infectivity alone. The difficulty collecting information illustrates that no adequate tracking system of infected pregnant women exists. Recommended is the creation of a formal database that includes standardized information such as the viral load of HIV or HCV at delivery, so that outcomes of intrapartum management can be more effectively assessed. No comment can be made on virus-related pregnancy complications, as study numbers are too small for statistically valid data.

KEY WORDS: Human Immunodeficiency Virus, Hepatitis C, Hepatitis B, Pregnancy, Disease Management, Antiretroviral Therapy

\section{INTRODUCTION}

Human Immunodeficiency Virus (HIV), hepatitis B (HBV) and hepatitis $\mathrm{C}(\mathrm{HCV})$ are important bloodborne viruses with significant morbidity and mortality and proven vertical transmission( $1,2,3)$. Until recently

* To whom correspondence should be addressed: 11 Sciennes Gdns, Edinburgh, EH9 1NR. Email: wends@doctors.org.uk
HIV and HBV were only tested for in those patients perceived to be at risk of exposure. However, with growing understanding of how and when vertical transmission occurs, and proven interventions to reduce this, routine optional antenatal screening was introduced in 1999 to identify infected women with no obvious risk factors. 


\section{Human Immunodeficiency Virus}

HIV has a high morbidity and mortality resulting in significant treatment and care costs. Although incurable, antiretroviral agents can increase the life expectancy of those infected by slowing viral replication and lowering viral load in the body before irreversible damage to the immune system occurs (4). Via this mechanism they then reduce the chances of the transmission to a child of an infected woman during pregnancy or labour. However, high viral turnover and mutation rates lead to drug resistance and therefore the use of several drug categories is becoming common practice. As resistance grows within the HIV infected population, methods to reduce transmission are becoming ever more important.

Globally women account for $47 \%$ of those living with HIV,5 and they are becoming increasingly infected. The vertical transmission rate is $15-40 \%$ (6),and is influenced by preterm delivery (7), prolonged membrane rupture ( $>4$ hours) (7), advanced disease, high viral loads and breastfeeding $(1,8,9)$.

Antenatal diagnosis allows time for management planning producing a greater chance of undetectable viral loads at delivery, and identifies infected women without obvious risk factors before symptomatic presentation. Each year over 300 HIV infected women give birth in the United Kingdom, two thirds of which are in London(8). This produces an HIV infection rate of $<3 / 10,000$ pregnancies(9).

Children who become infected during birth progress to symptomatic HIV and AIDS at a faster rate without treatment (8-10years) (1). However, universal screening allows at-risk children to be followed up for early diagnosis and treatment, providing a greater prospect of years of healthy normal development (2).

In 1994 the first regime to reduce vertical transmission was developed. The aim was to lower maternal viral load, avoid neonatal contact with infected maternal fluids and treat any transmitted virus. Large multi-centre, randomised, placebo-controlled trials of antiretroviral therapy (ART) and several meta-analyses of large prospective studies into mode of delivery show that antenatal, intrapartum and neonatal ART, a Caesarean delivery and abstinence from breastfeeding reduces the vertical transmission rates to $<5 \%$ $(8,9,10,11,12)$. Due to the success of this management, routine screening was introduced in Scotland with an aim to get $90 \%$ of pregnant women to accept the tests to therefore identify $80 \%$ of HIV infected women by mid2003 (6).

When diagnosing HIV in the child of an infected mother, the standard enzyme linked immunosorbent assay (ELISA) test for IgG is not suitable until after 18 months of age due to transplacental passage of maternal antibodies. Therefore a polymerase chain reaction (PCR) for viral RNA is used in the early months alongside health checks in follow-up. A confidential voluntary surveillance system of these children is in place over the UK (the Collaborative HIV Paediatric Study of UK and Ireland or CHIPS) from which transmission rates and disease progression statistics are taken.

\section{Hepatitis B Virus}

HBV infection can cause serious disease including liver failure, cirrhosis and hepatocellular carcinoma. The infection can be asymptomatic but around $10 \%$ of infected adults, and $90 \%$ of infected neonates, become long-term carriers with a $25 \%$ lifetime risk of cirrhosis (13). Due to rising drug addiction and immigrant populations, chronic carriers are more frequently seen in the UK (14). Co-infection with HIV makes HBV a more severe disease, resulting in prolonged illness, more complications, and a larger number of chronic carriers.

Without treatment, vertical transmission is $10-20 \%$ and linked to infectivity (3) and perhaps foetal exposure in threatened abortion or pre-term labour. Immunization is a successful and safe procedure used for many at risk populations throughout the world, and in some areas, is now part of the routine vaccination protocol. For postexposure protection (including infants born to infected women), vaccination and $\operatorname{IgG}$ is available with $90 \%$ efficacy if given within 12 hours (13). After this time, breastfeeding is not contraindicated (15) and the general practitioner completes the vaccination programme.

Selective screening of those "at risk" during pregnancy fails to identify $30-50 \%$ of infected women, and because the interventions are simple to implement, universal screening has been introduced.

\section{Hepatitis C Virus}

Like HBV, HCV can be a serious disease, with up to $80 \%$ of those infected becoming chronic carriers and $20 \%$ of those developing cirrhosis over 20 years. 16 However, unlike HBV, there is no vaccination for $\mathrm{HCV}$. Due to a long asymptomatic incubation, estimating prevalence of $\mathrm{HCV}$ in the population is difficult. Available data does suggest that approximately $3 \%$ of the world's population is infected with HCV (with about $2.5 \%$ of Europeans)(16) and one large Italian study found that $2.4 \%$ of pregnant women had anti-HCV antibodies with $72 \%$ of them positive for HCV-RNA (17) The group most at risk of contracting HCV are the intravenous drug abusers with up to $90 \%$ infected in some studies $(16,18)$, and again, co-infection with HIV worsens the prognosis with more rapid progression to liver failure (19). 
Originally HCV was managed with Caesarean section and avoidance of breastfeeding, but recent clinical trials show no benefit from this, 18,20,21 and currently the risk of vertical transmission is $<5 \% 20$. However this is increased if the mother is viraemic for $\operatorname{HCV}(20,22,23)$. Therefore, while $\mathrm{HCV}$ is readily detectable and arguably prevalent in some areas, the low transmission rates and the lack of effective interventions to reduce the rate further, make routine screening inappropriate at present. Despite this, when infected with HCV and HIV, not only does the risk of HCV transmission double (20), but transmission of HIV increases also (20). This makes HIV management issues even more critical and so, patients "at risk" of having HCV (for example IV drug abusers), are often tested for this virus when pregnant.

\section{AIMS}

This article aims to look retrospectively at a cohort of HIV, HBV and HCV-positive pregnancies from 1997 to 2002 in Edinburgh, to study the interventions implemented in their management. Current information about the diseases and recommendations or ideas pertaining to their management will be explored, alongside data collected from the study case records including: timing of diagnosis, uptake of planned interventions, and pregnancy outcomes (post-partum haemorrhage, gestation, birth-weight and infectious status of the child).

\section{METHODS}

Inclusion criteria were $\mathrm{HIV}, \mathrm{HBV}$ and $\mathrm{HCV}$ infected women, previously and newly diagnosed, who gave birth to a live infant from 1st September 1997 to 31st August 2002 (a total of 5 years) at the Royal Infirmary of Edinburgh and later, when the hospital moved sites, the New Royal Infirmary of Edinburgh.

Several selection methods were used to find patients. Previously diagnosed women who had antenatal viral loads measured, and patients newly diagnosed in pregnancy were found by a virologist in laboratory antenatal records. The midwife specifically looking after the HIV and HBV-positive pregnancies had created a list of names that was utilised. A paediatrician following up the children of these pregnancies helped the midwife to work back from the children's names she had, to their mother's. Finally, from the women found by the above methods, the computer system in the obstetric department was used to identify any other pregnancies over the selected time period.

The obstetric records of these patients were collected and pre-selected data were gathered from them. Data not included were pregnancies resulting in miscarriage or termination, women who moved out of Edinburgh to deliver, notes that could not be found and women who could not be traced from their child's name (often the family name would be changed after delivery). Many of the $\mathrm{HCV}$ cases relied on this trace-back method, as there is no other database of affected pregnancies, and thus, many HCV affected pregnancies could not be identified for inclusion. However, most of the known $\mathrm{HIV}$ and $\mathrm{HBV}$-positive pregnancies were included in the study.

\section{RESULTS \\ Study Groups}

Table 1 displays the numbers of pregnancies, number of affected women and numbers of deliveries for each viral group.

\section{Timing of diagnosis}

Each pregnancy of each woman was counted as an Table 1. Number of pregnancies in each disease category

\begin{tabular}{lllll}
\hline Disease & $\begin{array}{l}\text { Number of } \\
\text { pegnancies }\end{array}$ & $\begin{array}{l}\text { Number of } \\
\text { women }\end{array}$ & $\begin{array}{l}\text { Number of } \\
\text { sets of twins }\end{array}$ & $\begin{array}{l}\text { Infants } \\
\text { delivered }\end{array}$ \\
\hline $\begin{array}{l}\text { HIV-positive } \\
\text { (total) }\end{array}$ & 17 & 16 & 2 & 19 \\
$\begin{array}{l}\text { HBV-positive } \\
\text { (total) }\end{array}$ & 17 & 15 & 0 & 17 \\
$\begin{array}{l}\text { HCV-positive } \\
\text { (total) }\end{array}$ & 7 & 7 & 0 & 7 \\
$\begin{array}{l}\text { HIV-, HBV- } \\
\text { positive }\end{array}$ & 0 & 0 & 0 & 0 \\
$\begin{array}{l}\text { HIV-, HCV- } \\
\text { positive }\end{array}$ & 3 & 3 & 0 & 3 \\
$\begin{array}{l}\text { HBV-, HCV- } \\
\text { positive }\end{array}$ & 0 & 0 & 0 & 0 \\
$\begin{array}{l}\text { HIV-, HBV- } \\
\& \text { HCV- } \\
\text { positive }\end{array}$ & 0 & 0 & 0 & 0 \\
\hline \begin{tabular}{l} 
Total \\
\hline
\end{tabular} & 38 & 35 & 2 & 40 \\
\hline
\end{tabular}

1. Twin pregnancies were counted as one pregnancy but two infants. 2. Three women had more than one pregnancy during the time period: each pregnancy counted as a separate event but the women were only counted once.

3. As women coinfected with HIV and HCV were counted in both the HIV (total) and HCV (total) groups;

the overall total number of pregnancies = $\mathrm{HIV}$ (total)+HBV(total)+HCV(total)-HIVandHCV.

4. Two HIV-positive women were Hep B core antibody positive but Hep B surface antigen negative (therefore having resolved HBV) and so were classed as HIV-positive only.

5. One woman with HIV also had HCV but, even though she was not viraemic at delivery, she was included in the co-infected HIV and $\mathrm{HCV}$ group. 
individual event. For each virus, approximately half of the cases, 9 of $17 \mathrm{HIV}$ cases, 7 of $17 \mathrm{HBV}$ cases and 4 of $7 \mathrm{HCV}$ cases, were prenatal diagnoses and the remaining, with the exception of one case of HBV, were picked up during antenatal testing. The diagnosis of this case of HBV was only made after delivery when a paediatrician questioned the need for neonatal vaccination for $\mathrm{HBV}$ due to the mother's country of origin (Senegal).

\section{Interventions for HIV infectivity.}

No two pregnancies to HIV-positive women were managed exactly the same way (Table 2). All women received antenatal antiretroviral therapy, however, the combinations of agents used and the timing of its initiation varied. Also only $35.5 \%$ received the recommended zidovudine infusion during labour. Reasons for these treatment variations included previous drug regimens of the women involved, their resistance patterns and their viral loads during pregnancy.

For 15 of the 19 infants born to infected women, treatment was recorded, and the most commonly used agent was zidovudine (Table 2). However, prescription length differed from three to six weeks, and combination therapy was used occasionally.

Overall, ART recommendations for HIV-positive pregnancies were followed but with individual tailoring, resulting in $15(88.2 \%)$ of the 17 pregnancies receiving combination therapy.

All but one of the HIV women delivered by Caesarean section (Table 3): 12 were elective because of the infection, with or without a history of previous sections, and 4 required an emergency procedure for spontaneous labour, twins, or placenta praevia.

Prolonged membrane rupture has been linked to increased rates of vertical transmission, however, with limited patient numbers, there is difficulty calculating averages for this. Following recommendations, none of the HIV-positive women breast-fed.
Table 3. Delivery Routes

\begin{tabular}{lllll}
\hline $\begin{array}{l}\text { Delivery } \\
\text { Route }\end{array}$ & $\begin{array}{l}\text { HIV-positive } \\
\text { (total) }\end{array}$ & $\begin{array}{l}\text { HBV-positive } \\
\text { (total) }\end{array}$ & $\begin{array}{l}\text { HCV-positive HIV-, HCV } \\
\text { (total) }\end{array}$ & $\begin{array}{l}\text { p o s i t i v e } \\
\text { (total) }\end{array}$ \\
\hline $\begin{array}{l}\text { Spontaneous } \\
\text { Vertex }\end{array}$ & $1(5.9 \%)$ & $9(52.9 \%)$ & $3(42.9 \%)$ & 0 \\
Forceps & 0 & $3(17.6 \%)$ & 0 & 0 \\
$\begin{array}{l}\text { Elective } \\
\text { Caesarean }\end{array}$ & $12(70.6 \%)$ & $2(11.8 \%)$ & $2(28.6 \%)$ & $2(66.7 \%)$ \\
$\begin{array}{l}\text { Emergency } \\
\text { Caesarean }\end{array}$ & $4(23.5 \%)$ & $3(17.6 \%)$ & $2(28.6 \%)$ & $1(33.3 \%)$ \\
\hline $\begin{array}{l}\text { Total Number } \\
\text { of deliveries }\end{array}$ & 17 & 17 & 7 & 3 \\
\hline
\end{tabular}

1. Pregnancies to women co-infected with HIV and HCV were counted in [HIV-positive (total)], [HCV-positive (total)] and [HIV and HCV-positive (total)] categories

2. As there were no women with HIV plus HBV or HBV plus HCV or HIV plus HBV plus HCV, these categories are omitted from the table

\section{Interventions for Hepatitis B infectivity.}

The majority (70.5\%) of deliveries for HBV-positive women were vaginal (Table 3). Reasons recorded to explain the use of Caesarean sections were mainly obstetric, however, in contrast to recommendations at the time, one woman, with low infectivity, was stated to have had a section partly because of her HBV status.

Following recommended protocol, all neonates received immunoglobulin and the initial vaccination dose at birth, and all then went on to be breastfed. The remaining vaccination doses were to be given at one and six months by the child's general practitioner.

\section{Interventions for Hepatitis $\mathbf{C}$ infectivity}

Of the 4 women infected solely with $\mathrm{HCV}, 3$

Table 2: Antiretroviral therapy for HIV

\begin{tabular}{|c|c|c|c|c|c|c|}
\hline & $\begin{array}{r}\text { D } \\
\text { MonoTherapy }\end{array}$ & $\begin{array}{l}\text { uring Pregnancy } \\
\text { Combination Therapy }\end{array}$ & IV infusion & $\begin{array}{l}\text { During Labour } \\
\text { Mono-therapy }\end{array}$ & $\begin{array}{r}\text { Neonatal } \\
\text { Combination Therapy }\end{array}$ & Undiscolsed \\
\hline $\begin{array}{l}\text { Number } \\
\text { (\% of total) }\end{array}$ & $2(11.8)$ & 15 (88.2) & $6(35.5)$ & $9(47.4)$ & $6(31.6)$ & $4(21.1 \%)$ \\
\hline $\begin{array}{l}\text { Drugs used } \\
\text { (descending } \\
\text { order of use) }\end{array}$ & Zidovudine & $\begin{array}{l}\text { Zidovudine } \\
\text { Lamivudine } \\
\text { Nevirapine } \\
\text { Nelfinavir } \\
\text { Abacavir } \\
\text { Stavudine } \\
\text { Didanosine }\end{array}$ & Zidovudine & $\begin{array}{l}\text { Zidovudine } \\
\text { Nevirapine }\end{array}$ & $\begin{array}{l}\text { Zidovudine } \\
\text { Nevirapine } \\
\text { Lamivudine } \\
\text { Abacavir } \\
\text { Nelfinavir }\end{array}$ & \\
\hline
\end{tabular}


delivered vaginally (Table 3 ). The reason stated for the use of Caesarean for the other delivery was based on obstetric as opposed to infectious grounds. The women co-infected with HIV and HCV all received Caesareans. Women with HCV only were advised to breastfeed, and for reasons not stated, only one of the 4 decided to do so.

\section{Infectivity of the mother at delivery}

Vertical transmission risks are associated with a high HIV or HCV viral load or "highly infectious" HBV $(3,9,18)$. Highly infectious HBV is diagnosed by a positive titre for hepatitis $\mathrm{B}-\mathrm{e}$ antigen $(\mathrm{HBeAg})$ and a negative titre for the antibody to the e antigen ( $\mathrm{HBeAb})$, therefore the virus is actively replicating without an adequate immune response. Measuring viral load at delivery can also be used to assess the efficacy of the antenatal management of HIV.

The aim of antiretroviral therapy is to achieve an undetectable viral load at delivery $(<50$ copies $/ \mathrm{ml})$ and this was achieved in 8 of the 17 pregnancies $(47.1 \%)$. Unfortunately, three of the deliveries had no viral load recorded, and ART did not achieve maximal effect for one woman who delivered with a high viral titre of 254,000 copies $/ \mathrm{ml}$. The numbers are too small to know if the timing of treatment initiation influences viral load at delivery.

For HBV 6 of the 17 deliveries (31.6\%) were highly infectious at delivery (see above for criteria), and the remaining 11 (57.9\%) were carriers with low infectivity (HBeAg negative and $\mathrm{HbeAb}$ positive). The criteria for having resolved $\mathrm{HBV}$ is a positive titre for hepatitis $\mathrm{B}$ core antibody ( $\mathrm{HbcAb}$ ) and a negative titre for hepatitis B surface antigen (HBsAg) showing previous infection. Two women had resolved HBV but because they were not infectious, they were not included in the HBV infected study group.

There is no routine measurement of HCV viral load, and therefore the data could not be included.

\section{Infective status of the child}

Of the 19 children born to HIV-positive women in this study, 7 currently have indeterminate infectious status (too young at the study conclusion to reliably determine a diagnosis), 11 are HIV-negative (antibody negative on at least two occasions) and only one was found to be infected in follow-up but is asymptomatic on ART at 18 months (Table 4). It was not possible at the time of writing this article to determine the delivery route of this child.

As the General Practitioner follows-up children born to HBV-positive women, the precise number of transmissions is unknown; however, from the sources approached there are no known cases.

Children born to mothers infected with $\mathrm{HCV}$ are
Table 4. Infectious status of the children

\begin{tabular}{llll}
\hline Status & HIV & HBV & HCV \\
\hline Positive & $1(5.4 \%)$ & 0 & 0 \\
Negative & $11(57.9 \%)$ & $17(100 \%)$ & $17(100 \%)$ \\
Indeterminate & $7(36.8 \%)$ & 0 & 0 \\
\hline Total & 19 & 17 & 7 \\
\hline
\end{tabular}

followed up by the same paediatrician as the HIV cases, but receive no interventions. There are no reported neonates with $\mathrm{HCV}$.

Table 5. Pregnancy Outcomes

\begin{tabular}{|c|c|c|c|c|}
\hline Outcome & $\begin{array}{l}\text { HIV- } \\
\text { positive } \\
\text { only }\end{array}$ & $\begin{array}{l}\text { HBV- } \\
\text { positive } \\
\text { only }\end{array}$ & $\begin{array}{l}\text { HCV- } \\
\text { positive } \\
\text { only }\end{array}$ & $\begin{array}{l}\text { HIV- and } \\
\text { HCV } \\
\text { positive }\end{array}$ \\
\hline $\begin{array}{l}\text { Average } \\
\text { delivery } \\
\text { gestation (wks) }\end{array}$ & 36 & 39 & 36 & 38 \\
\hline $\begin{array}{l}\text { Numbers } \\
\text { preterm } \\
\text { (<37 weeks) }\end{array}$ & $\begin{array}{l}5 \mathrm{NB} \\
\text { includes } \\
4 \text { twins }\end{array}$ & 3 & 1 & 0 \\
\hline $\begin{array}{l}\text { Average } \\
\text { blood loss } \\
\text { for delivery } \\
(\mathrm{ml})\end{array}$ & 439 & 415 & 288 & 483 \\
\hline $\begin{array}{l}\text { Number } \\
\text { with PPH } \\
\text { (postpartum } \\
\text { heamorrhage) } \\
(>500 \mathrm{ml})\end{array}$ & 2 & 3 & 0 & 1 \\
\hline $\begin{array}{l}\text { Number } \\
\text { with signi- } \\
\text { ficant PPH } \\
(>1000 \mathrm{ml})\end{array}$ & 1 & 1 & 0 & 1 \\
\hline $\begin{array}{l}\text { Average } \\
\text { birthweight } \\
\text { (g) }\end{array}$ & $\begin{array}{l}2644 \\
\text { (3589 without } \\
\text { twins) }\end{array}$ & 3266 & 2258 & 2697 \\
\hline $\begin{array}{l}\text { Number } \\
\text { with low } \\
\text { birth weight } \\
(<2500 \text { g at tern }\end{array}$ & $\begin{array}{l}4 \\
\text { NB all twins } \\
\text { m) }\end{array}$ & 0 & 2 & 1 \\
\hline $\begin{array}{l}\text { Number of } \\
\text { infants } \\
\text { requiring } \\
\text { time in neo- } \\
\text { natal unit } \\
\text { and why }\end{array}$ & $\begin{array}{l}7 \\
=4 \text { twins } \\
+1 \text { premature } \\
+2 \text { withdrawal }\end{array}$ & $\begin{array}{l}3 \\
=2 \text { preterm } \\
+1 \text { meconium }\end{array}$ & $\begin{array}{l}1 \\
=1 \text { preterm }\end{array}$ & $\begin{array}{l}1 \\
=1\end{array}$ \\
\hline
\end{tabular}

1. For HIV there were 17 pregnancies, resulting in 19 infants (ie 2 twin pregnancies).

2. Multiple pregnancies result in earlier delivery and smaller infants. 


\section{Effect on pregnancy}

On planning this study it was hoped that information about the effect of these viruses on various pregnancy outcomes could be assessed, however it soon became apparent that study numbers were not large enough to take into account confounding factors and calculate valid statistical data. The averages for the measured outcomes are included in Table 5 for interest.

Overall, average gestation and birth weight for non-twin pregnancies were adequate and no major adverse outcomes linked to the viruses could be noted.

\section{DISCUSSION}

The aims of this article were to look back over pregnancies affected by HIV, HBV and HCV (or any combination) from September 1997 to August 2002 and study their management. It also hoped to look at the effects these viruses had on various pregnancy outcomes and review current understanding about recommendations for the management of these virus.

\section{Human Immunodeficiency Virus}

Because HIV is currently incurable, reducing the spread is a vital part of management on a global scale. Vertical transmission from mother to unborn child is one area that can readily be addressed with effective interventions $(8,9,10,11,12)$. Because of this, universal antenatal screening for HIV was recently introduced with an aim to identify previously unrecognised infected pregnancies and allow appropriate management(6). From the start of September 1997 until the end of August 2002 informed estimates put the number of deliveries in Edinburgh at around 32,000. From these, $17 \mathrm{HIV}$ infected pregnancies to 16 women that resulted in 19 live infants were identified. Around half of these pregnancies were known about before the booking appointment for antenatal care, and the remainder were detected via the routine antenatal screening. It is encouraging to see that the HIV screening is working in its aim to identify previously unknown infections.

While there was no clear pattern to the choice of antiretroviral agent or when it was initiated, there was $100 \%$ uptake of ART in some form for the pregnancies. There are many reasons as to why therapy differed from patient to patient. Historically zidovudine (a nucleoside reverse transcriptase inhibitor or NRTI) was the first anti-HIV drug to be introduced. Initially it was used as monotherapy in the management of HIV in pregnancy and is still used as an infusion during labour to reduce intrapartum transmission(7), and for neonatal treatment after delivery. But due to the high replication and mutation rates of HIV, resistance is a growing concern. Because of this, combination ART is increasingly being used. By utilising agents with different sites of action (often by using two NRTIs with or without a Protease inhibitor or non-NRTI1) there is less selection pressure for a resistant strain and control is more effective. The choice of which agents to use within a combination regimen depend on the resistance patterns of the virus within each patient, the tolerability of the side effects produced and the pattern of interactions between the drugs. For these reasons, the ART regimen must be individualised for each patient, and revised if necessary throughout treatment.

In this study $88.2 \%$ of the pregnant women received combination ART which is in line with current recommendations(1), and because of this, nearly half of the deliveries were with an undetectable viral load.

As the use of any drug during pregnancy raises concern about the safety to the developing unborn child, there have been studies into the outcomes of in utero exposure to ART. Although more research into the longterm effects of ART is needed, two large multi-centre, randomised, double-blind, placebo-controlled cohorts of in utero exposure to zidovudine and combination therapy, found no associated risk of adverse short or long term outcomes $(24,25)$.

Due to the efficacy of combination therapy, which results in so many women with the ideal undetectable viral load at delivery, there is now increasing discussion about the need for Caesarean sections to avoid infant contact with maternal fluids. By avoiding surgical intervention, risks and recovery times for the mother are reduced and she also gains more choice and empowerment over the birth of her child. While most women in this study received either an elective or emergency section, there was one mother who was allowed a vaginal delivery because she had undetectable virus. This may reflect the transfer of these academic discussions into clinical practice, however there are no clear studies to support the safety of these proposals yet.

While the avoidance of breastfeeding may not be appropriate in developing countries where the availability of safe water and affordable formula feed mean that mortality and morbidity from infection outweighs the benefits of avoiding HIV contraction, in the UK this is generally not the case. All HIV-positive women should be advised not to breastfeed their child, despite receiving neonatal ART. In this study, no women breastfed.

Very encouragingly there was only one reported case of vertical transmission over the 5 years, and because the infective status of the mother was known, the child was diagnosed asymptomatically thus allowing optimal ART management, resulting in a healthy, active child at 18 months of age. 
In summary, the current antenatal screening is effective in detecting unrecognised infected women. While treatment was individualised, the management recommendations of antenatal and neonatal ART, a caesarean delivery and the avoidance of breastfeeding were followed in this study. Because of these measures there was only one reported case of vertical transmission, and the child remained well on ART.

\section{Hepatits B Virus}

HBV can be a serious condition with risks of cirrhosis and hepatic failure. There is a $10-20 \%$ risk of vertical transmission(3) which can be virtually eliminated by passive-active immunization (administering a dose of IgG and following the vaccination schedule) within 12 hours of delivery(13). Because of this, HBV testing is part of the antenatal screening protocol.

There were 17 pregnancies to 15 women producing 17 live infants in Edinburgh over the study period. Over half of the pregnancies were diagnosed by screening, and there was $100 \%$ uptake of the interventions offered up to the initial vaccination. This shows that, like HIV screening, testing for antenatal $\mathrm{HBV}$ is effective in detecting unidentified infected pregnancies. The safe and effective interventions are readily accepted and although there is no central follow-up of these children, there have been no reported cases of vertical transmission in Edinburgh over the study's duration.

\section{Hepatitis C Virus}

HCV can also be a serious condition but unlike HBV there is no vaccination currently available. The major risk factor for its contraction is intravenous drug abuse, and its prevalence in that population may be high(16,18). Due to a long asymptomatic period, calculating the overall prevalence is difficult, but estimates put $2.5 \%$ of the European population infected(16).

Risk factors for paediatric infection include motherto-child transmission and transfusion or transplantation of infected fluids or tissues $(2,16)$. Since the routine screening of blood products and organs for $\mathrm{HCV}$ in 1991(2), the mother-to-child route will become an ever more significant risk factor. Currently the vertical transmission risk is $<5 \%(20)$, but that is increased in proportion to levels of viraemia at delivery(20,22, 23).However, as caesarean delivery and avoiding breastfeeding does not reduce this $\operatorname{risk}(18,20,21)$ routine screening is not recommended.

One amendment to this recommendation is coinfection with HIV. Not only does the rate of $\mathrm{HCV}$ transmission increase, but also the risk of contracting HIV is raised(20). This means that when HIV-positive women are at risk of having $\mathrm{HCV}$, testing is recommended as the HIV management issues become even more important.

This study found only 7 pregnancies to 7 women producing 7 live singleton infants, which is probably a small proportion of the actual number of HCV infected pregnancies over that time period as cases could only be selected from women already diagnosed or those deemed as at risk, who therefore received a HCV test during their antenatal care. The other route used to find candidates was via the children born to infected mothers who were known to a specialist paediatrician. This route was not productive however as the list did not include the mother's name, and often the children would have changed family names since delivery.

As a caesarean delivery is not recommended for $\mathrm{HCV}$ infection alone, it is encouraging to see that no woman was given a surgical delivery for $\mathrm{HCV}$ infectious status alone.

One aim of the study was to assess the infectivity of the mother at delivery, but as there was no standard viral load documentation this was not possible. Although useful for research purposes, routine HCV viral loads for HCV-only infected women would not change the management of the pregnancy. Therefore HCV viral load testing cannot be recommended as part of the antenatal care package.

There were no reported cases of vertical transmission in the children born to the women of this study.

\section{Secondary Findings}

Due to small study numbers, it was not possible to account for confounding influences on pregnancy outcomes and therefore it was inappropriate to take statistical data from these results. In the developing world, intrauterine HIV is associated with low birth weight and prematurity (14), however, averages for gestation and birth weight were not below the normal ranges in this study. In a developed country such as the United Kingdom this may be due to several factors: the high level of medical input resulting in low viral loads; the management of infections related to HIV; good nutrition during pregnancy or a combination of these. Despite not being able to acquire statistical data for pregnancy outcomes, a number of interesting secondary findings became apparent.

Firstly, the pool of knowledge about these viruses is continually growing. As such, the understanding of when and how transmission occurs, and what interventions influence this, result in recurrent updating of management recommendations.

Secondly, the difficulties met trying to find cases to include in this study illustrate that there is currently no adequate tracking system of HIV, HBV and HCV infected pregnancies in Edinburgh. This will be due, in 
part, to the low prevalence of these conditions in the population, unlike areas such as London where HIV, especially, is much more frequent.

Despite having several limitations, this study does illustrate important points in management and areas for further research such as vaginal delivery in HIV and long-term antenatal ART. Where these infections are less common, awareness should be raised about the need for service organisation to allow evaluation and improvement.

\section{ACKNOWLEDGEMENTS}

Many thanks to Dr K Dundas (Consultant Obstetrician at the New Royal Infirmary of Edinburgh), Dr M Ogilvie (Consultant Virologist at the New Royal Infirmary of Edinburgh), Dr J Mok (Consultant Paediatrician at the Royal Hospital for Sick Children in Edinburgh), Dr Liston (Consultant Obstetrician at the New Royal Infirmary of Edinburgh), Medical Microbiology and Medical Records at the New Royal Infirmary of Edinburgh and Fiona McNeillage (Midwife at the New Royal Infirmary of Edinburgh) for their help finding cases and information and for their support and guidance throughout this project.

\section{REFERENCES}

1. Duong T, Ades AE, Gibb DM, Tookey PA, Masters J. Vertical transmission rates for HIV in the British Isles: estimates based on surveillance data. BMJ 1999; 319:1227-29.

2. Gibb DM, Duong T, Tookey PA et al. Decline in mortality, AIDS, and hospital admissions in perinatally HIV-1 infected children in the United Kingdom and Ireland. BMJ 2003; 327(7422): 1019 .

3. Stevens CE, Neurath RA, Beasley RP, Szmuness W, HBeAg and anti-Hbe detection by radioimmunoassay: correlation with vertical transmission of hepatitis B virus in Taiwan. J Med Virol 1979; 3: 237-41.

4. British National Formulary. Issue 46. September 2003

5. National Institutes of Health Fiscal Year 2003: Plan for HIV related research URL: http://www.nih.gov/od/oar/public/pubs/ fy2003/ i_overview.pdf

6. Scottish Centre for Infection and Environmental Health Weekly Report: 25 June 2002; Volume 36, No. 2002/25. ISSN 13574493. p.156.

7. Kuhn L, Steketee RW, Weedon J et al. Distinct risk factors for intrauterine and intrapartum human immunodeficiency virus transmission and consequences for disease progression in infected children. Perinatal AIDS Collaborative Transmission Study. J Infectious Diseases 1999; 179(1): 52-58.

8. Public Health Laboratory Service: HIV and AIDS: Surveillance URL:http://www.phls.org.uk/topics_az/hiv_and_sti/hiv /epidemiology/ quarterly.htm
9. Communicable disease surveillance centre: HIV and AIDS in the UK. An epidemiological review: 2000.

10. Dunn et al. Mode of delivery and vertical transmission of HIV1: a review of prospective studies. Perinatal AIDS Collaborative Transmission Studies. J Acquir Immune Defic Syndr 1994; 7(10):1064-66.

11. Connor EM et al. Reduction of maternal-infant transmission of Human Immunodeficiency Virus Type 1 with zidovudine treatment. N Engl J Med 1994; 331:1173-80.

12. The International Perinatal HIV Group. The mode of delivery and the risk of vertical transmission of Human Immunodeficiency Virus type 1- A meta-analysis of 15 prospective cohort studies. N Engl J Med 1999; 340: 977-87.

13. Moyes CD, Smith L, Lennon D. Hepatitis B - prevention of perinatal transmission. NZ Med J 2002; 115:19-20.

14. Obstetrics. In: Collier J, Longmore M, Brown TD. Oxford Handbook of Clinical Specialities. 5th ed. Oxford University Press; 2001. p.76-169.

15. Hill JB, Sheffield JS, Kim MJ, Alexander JM, Sercely B, Wendel GD. Risk of hepatitis B transmission in breast-fed infants of chronic hepatitis B carriers. Obstet Gynecol 2002; 99(6): 1049-52.

16. WHO Consultation and the Viral Hepatitis Prevention Board. Global surveillance and control of hepatitis C. J Viral Hepatitis 1999; 6(1): 35-47.

17. Conte D, Fraquelli M, Prati D, Colucci A, Minola E. Prevalence and clinical course of chronic hepatitis $\mathrm{C}$ virus (HCV) infection and rate of HCV vertical transmission in a cohort of 15,250 pregnant women. Hepatology 2000; 31(3): 751-5.

18. Garland $\mathrm{SM}$ et al. Hepatits $\mathrm{C}$ - role of perinatal transmission. Aust NZ Obstet Gynaecol 1998; 38(4): 424-7.

19. Resti M, Azzari C, Bortolotti F. Hepatitis C virus infection in children coinfected with HIV: epidemiology and management. Paediatric Drugs 2002; 4(9): 571-80.

20. European Paediatric Hepatitis C Virus Network. Effects of mode of delivery and infant feeding on the risk of mother-to-child transmission of hepatitis $\mathrm{C}$ virus. Brit J Obstet \& Gynaecol 2001; 108: 371-7.

21. Tovo $P A$ et al. Increased risk of maternal-infant hepatitis $C$ virus transmission for women coinfected with human immunodeficiency virus type 1. Italian Study Group for HCV Infection in Children. Clin Infect Dis 1997; 25(5): 1121-4.

22. Thomas SL, Newell ML, Peckham CS, Ades AE, Hall AJ. A review of hepatitis $\mathrm{C}$ virus (HCV) vertical transmission: risks of transmission to infants born to mothers with and without $\mathrm{HCV}$ viraemia or human immunodeficiency virus infection. Int $\mathrm{J}$ Epidemiol 1998; 27(1):108.

23. Ohto $\mathrm{H}$ et al. Transmission of hepatitis $\mathrm{C}$ virus from mothers to infants. N Engl J Med 1994; 330:744-50.

24. Tuomala RE et al. Antiretroviral therapy during pregnancy and the risk of an adverse outcome. N Engl J Med 2002; 346: 186370.

25. Culnane $\mathrm{M}$ et al. Lack of long-term effects on in utero exposure to zidovudine among uninfected children born to HIV-infected women. JAMA 1999; 281:151-7.

Wendy Russell is a a final year medical student at Edinburgh University, UK. 